\title{
Adsorption of ceftriaxon by biogenic hydroxyapatite with magnetic additions
}

\author{
O.M.Otychenko ${ }^{1,2}$, T.Ye.Babutina ${ }^{1}$, O.A.Kuda ${ }^{1}$, O.M.Budylina ${ }^{1}$, \\ L.S.Protsenko ${ }^{1}$, O.Yu.Koval ${ }^{1}$, I.V.Uvarova ${ }^{1,2}$ \\ ${ }^{1}$ J. Frantsevich Institute for Problems of Materials Science, \\ 3 Krzhizhanovsky Str., 03680 Kyiv-142, Ukraine \\ ${ }^{2}$ National Technical University of Ukraine "I. Sikorsky Kyiv Polytechnic \\ Institute", 37 Peremogy Ave., 03056 Kyiv, Ukraine
}

Received April 23, 2017

\begin{abstract}
The possibility of using nanoporous composite system based on biogenic hydroxyapatite (BHA), which alloyed by ferromagnetic additives due to using two methods of physicochemical mixing, as a carrier of drugs for orthopedics and traumatology was shown. It was found that the sample obtained by precipitation previously prepared iron oxalate on the surface of BHA microspheres has a greater adsorption activity than the sample obtained by including BHA directly in the process of obtaining iron oxalate (300 and $175 \mathrm{mg} / \mathrm{g}$ respectively). However, due to the difference in porosity, they are capable to hold a different amount of the injected antibiotic mass: $6 \mathrm{wt} \%$ - for material obtained by physico-mechanical method and $10 \mathrm{wt}$ $\%$ - for the sample obtained by chemical method.
\end{abstract}

Keywords: biogenic hydroxyapatite, alloying, adsorption activity, ceftriaxon.

Показана возможность использования нанопористой композиционной системы на основе биогенного гидроксиапатита (БГА), легированного магнитными добавками при помощи двух способов конденсационного физико-химического метода, как носителя лекарственных средств для ортопедии и травматологии. Установлено, что образец, полученный через осаждение готового оксалата железа на поверхностях микрогранул БГА, имеет большую адсорбционную активность по сравнению с образцом, полученным при непосредственном введении БГА в процесс осаждения оксалата железа (300 и 175 мг/г соответственно), однако за счет разности пористостей они способны удерживать в себе разное количество массы введенного антибиотика: 6 масс.\% - материал, полученный физико-механическим способом; 10 масс.\% - образец, полученный химическим способом.

Адсорбція цефтріаксону біогенним гідроксиапатитом із магнітними добавками. О.М.Отиченко, Т.Є.Ю.Бабутіна, О.А.Куда, О.М.Будиліна, Л.С.Проценко, О.Ю.Коваль, I.В.Уварова.

Показано можливість використання нанопористої композиційної системи на основі біогенного гідроксиапатиту (БГА), легованого магнітними добавками з використанням двох способів конденсаційного фізико-хімічного методу, як носія лікарських засобів для потреб ортопедії та травматології. Встановлено, що зразок, отриманий через осадження готового оксалату заліза на поверхнях мікрогранул БГА, має більшу адсорбційну активність порівняно зі зразком, одержаним безпосереднім введенням БГА у процесі осадження оксалату заліза (300 та 175 мг/г відповідно), однак за рахунок відмінностей у пористостях вони здатні утримувати в собі різну кількість маси введеного антибіотику: 6 мас.\% - матеріал, отриманий фізико-механічним способом; 10 мас.\% - зразок, одержаний хімічним способом. 


\section{Introduction}

Development of technologies of producing materials for bone implants on the basis of calcium phosphates was caused by a necessity of overcoming the immune answer from organism on implanted metallic, allograft or xenograft. Each of the implants, except substantial advantages, has substantial defects [1-3]. Thus, stainless steel, titanium and its alloys are biologically inert, non-toxic and resistant to biochemical influence of the body whereas xeno- and allografts even being "dead" bone, slowly proliferate with surrounding cells and can transfer various diseases of bacterial or viral etiology from donor to recipient. Attempts to minimize these risks through intensive heat treatment led only to reduction of the osteoinductive properties and mechanical strength of almost $50 \%$, but the possibility of infection wasn't completely eliminated. Besides, the use of autografts for transplantation are limited by amount withdrawed material and leads to increase in terms of surgical interference, blood loss and prolonged hospitalization [4,5].

At the same time, over the past few decades of wide application of hydroxyapatite $\left(\mathrm{Ca}_{10}\left(\mathrm{PO}_{4}\right)_{6} \mathrm{OH}_{2}\right)$ in osteoplactic surgery, it acquired significance as compoud identical to mineral component of bone $[6,7]$. It should be noted that the mechanical properties of such bioactive and resorptive ceramics are signified only in very short period because of substitution by bone that removes all related problems. At that, bioceramics as all the achievements of modern materials, continuously are improved through development of alternative types of materials alloyed with different chemical elements or compounds that now there are hundreds [8]. Powder based on iron was no exception too.

In particular, in composite system the biogenic hydroxyapatite (BHA) alloyed by magnetite ( $\mathrm{FeO} \cdot \mathrm{Fe}_{2} \mathrm{O}_{3}$ ) plays the role of magneto-sensitive component with a reactive surface and BHA is a thin layer of stabilizator [9, 10]. In addition, if the first composites with additions of iron or its compound were developed primarily for controlled drug delivery [11-13], then in the field of orthopedics they started to be used as fine accumulators of antibiotics designed to further reduction of the risk of infection or chronic granulomatous inflamation after implantation [14].
To load the material bone cavity fillers in medicine, there are mostly used the broad spectrum antibiotics with antimicrobial action - cefazolin [15], gentamicin, rifampicin [16-19] and others. Over the last decade the most appointed antibiotics (38.2\%) were cephalosporins [20] that operate on sensitive organisms in the stage of active multiplication [21]. Therefore, to study the adsorption activity of compact samples of BHA doped by nanomagnetite, the ceftriaxon is chosen as a drug of the third generation of cephalosporins, which is characterized by high activity against gramnegative enterobacteria [22] as well as a drug which has the longest (5-7 h) half-life among other cephalosporins. The drug has the high degree of protein binding and dual output path [23].

The purpose of this work is to investigate interaction of composite systems based on biogenic hydroxyapatite (BHA) alloyed with magnetic additions and antibiotics.

\section{Experimental}

As an object of the research it was chosen the biomaterial "Osteoapatyt Keramichniy"(r) (Ukraine) obtained from cattle bone tissue in a form of microgranules [24]. It alloyed by ferromagnetic particles due to using two methods of physicochemical mixing. The number of reagents was chosen based on the final amount of iron not more than $1.5 \%$ mass. [25]. In the first case the alloyed powder material was obtained by including BHA directly in the process of obtaining iron oxalate (chemical method) through mixing hydrosuspension of $\mathrm{BHA}$ stabilized by sucrose and isopropanol with solutions of $\mathrm{FeSO}_{4} \cdot 7 \mathrm{H}_{2} \mathrm{O}$ and $\mathrm{H}_{2} \mathrm{C}_{2} \mathrm{O}_{4} \cdot 2 \mathrm{H}_{2} \mathrm{O}$ and as a result of chemical interaction between them dehydrate iron oxalate was precipitated on the BHA surface. In the second case previously prepared iron oxalate was precipitated on the BHA surface as hydromixture (physico-mechanical method). Subsequently filtering, dehydration, and drying of obtained condensation disperse system was carried out [26].

The compact samples of pure BHA and alloyed materials of cylindrical shape $(d=$ $10 \pm 0.2 \mathrm{~mm}$ ) with mass $1.8 \pm 0.3 \mathrm{~g}$ were obtained by dry pressing (10 MPa). Subsequently low temperature thermolysis in a nitrogen medium at $500^{\circ} \mathrm{C}$ (below the Curie point for magnetite $-572^{\circ} \mathrm{C}$ ) for $2 \mathrm{~h}$ was carried out. 
The specific surface area of the biomaterials was determined by method of thermal desorption of nitrogen by "MPP2" device [27].

The phase composition of the powder materials was controlled by X-ray diffractometer "DRON-3.0" under Co- $\mathrm{K}_{\alpha}$ radiation.

Adsorption activity was determined using ceftriaxon (Ceftriaxon, "Arterium", Ukraine) - $\beta$-lactam semisynthetic broad spectrum antibiotic. Ceftriaxon (Fig. 1) is white crystalline powder which is soluble in water, medium soluble in methanol, and slightly - in ethanol. Color of the ceftriax on solution changes from yellow to amber, depending on the storage temperature, concentration and solvent applied.

In our work quite simple and widely used but non-standart drug adsorption procedure, prescribed in GOST 4453-74 [17], was selected. It will not reduce to additional financial, time or organizational means in the future.

The antibiotic solutions were prepared immediate before experiment by methodology, developed by the authors of this article, taking into account the period of drugs half-life. As disolvent $0.9 \%$ sodium saline ("Arterium", Ukraine) was applied. Studied samples were placed into special bottles and the antibiotic solutions were slowly added. According to prescription letter on the mentioned antibiotic for intramuscular injection it was used concentration of 286 thousands $\mathrm{mg} / \mathrm{l}$ ( $1 \mathrm{~g}$ of preparation on $3.5 \mathrm{ml}$ of lidocaine or sodium saline), and for intravenous - 100 thousands $\mathrm{mg} / \mathrm{l}$ (1 $\mathrm{g}$ antibiotic to $10 \mathrm{ml}$ solution for injection). In this regard, it was chosen the initial concentration of ceftriaxon, which was less than both, namely $\sim 56$ thousands $\mathrm{mg} / \mathrm{l}$. Subsequently, the bottles were closed and left at the room temperature $\left(22-24^{\circ} \mathrm{C}\right)$ for $4 \mathrm{~h}-$ one half of half-life. When the time of experiment is out the antibiotic solutions were placed into test-tubes and centrifugeted for $10 \mathrm{~min}$ ( $n=3000 \mathrm{rpm} / \mathrm{min}$ ) with the purpose of elimination of any particles from the studied materials. The surface of the compact samples were studied after complete drying at the temperature which is not exceed $25^{\circ} \mathrm{C}$. Amount of the drug in the solution after contact for $4 \mathrm{~h}$ with the compact samples was determined by the calibration schedule for ceftriaxon.

The antibiotic concentration was determined using photoelectrocalorimetric method by "FEC-56M" device and calibration schedule of optical dense ceftriaxone solutions depending on their concentration.<smiles>CO/N=C(\C(=O)N[C@H]1C(=O)N2C(C(=O)O)=C(CSc3nc(=O)c(=O)[nH]n3C)CS[C@H]12)c1csc(N)n1</smiles>

Fig. 1. Structural formula of ceftriaxon $\mathrm{C}_{18} \mathrm{H}_{18} \mathrm{~N}_{8} \mathrm{O}_{7} \mathrm{~S}_{3}$.

Adsorption activity in reference to ceftriaxon was determined by formula (1):

$$
X=\frac{\left(C_{1}-C_{2} K\right) V}{m},
$$

where $C_{1}-$ mass concentration of starting solution of antibiotic, $\mathrm{mg} / \mathrm{l} ; C_{2}-$ mass concentration of antibiotic solution after interaction with material, $\mathrm{mg} / \mathrm{l} ; K-$ coefficient of solution dilution which is taken for analysis; $m$ - mass of the sample, $\mathrm{g} ; \mathrm{V}-$ volume of antibiotic solution which is taken for research, ml.

The samples mass was determined on the analytical balance of "OHAUS Pioneer PA214C" firm ("OHAUS Corporation", China) with an accurate within $0.0001 \mathrm{~g}$.

Surface morphology of the compact materials was studied using the microscope "JEOL Superprobe 733" with gold (Au) deposition.

\section{Results and discussion}

Technological process of obtaining the pressed samples foresees the stage of controlling the chemical composition of the studied materials on carbon and iron contents because of them excessive quantities can be harmful to human organism. Thus, with increased content of the both elements the inflamation is mainly absent [28], but increasing the amount of iron to more than 2 wt.\%. it could to disturb homeostasis and inhibit the growth of osteoblasts [29], which in our case is undesirable. In order to determine the chemical composition, specific surface area and phase composition one sample of each materials after thermolysis in nitrogen medium was crashed to powder condition. The results of its chemical analysis showed in Table 1.

Numerous research of phase composition of above mentioned powder material after 
Table 1. Results of chemical analysis of studied samples

\begin{tabular}{|c|c|c|c|}
\hline Material & Thermolysis medium & $\begin{array}{c}\text { Content } C_{\text {total }}, \quad \% \\
\text { mass. }\end{array}$ & $\begin{array}{c}\text { Content } \mathrm{Fe}_{\text {total }}, \% \\
\text { mass }\end{array}$ \\
\hline BHA $(<160 \mu \mathrm{m})$ & \multirow{3}{*}{$\begin{array}{l}\text { nitrogen medium, } \\
500^{\circ} \mathrm{C}, 2 \mathrm{~h}\end{array}$} & 0.03 & 0.08 \\
\hline $\mathrm{BHA}+\mathrm{Fe}_{3} \mathrm{O}_{4}$, chem. method & & 0.86 & 0.98 \\
\hline $\mathrm{BHA}+\mathrm{Fe}_{3} \mathrm{O}_{4}$, ph.-mech. method & & 0.86 & 1.29 \\
\hline
\end{tabular}

Table 2. Physical characteristics of compact samples after thermolysis in nitrogen medium $\left(500^{\circ} \mathrm{C}, 2 \mathrm{~h}\right)$

\begin{tabular}{|c|c|c|c|}
\hline \multirow[t]{2}{*}{ Material } & \multirow{2}{*}{$\begin{array}{l}\text { Specific surface } \\
\text { area, } \mathrm{m}^{2} / \mathrm{g}\end{array}$} & \multicolumn{2}{|c|}{ Porosity, \% } \\
\hline & & Total & Open \\
\hline BHA $(<160 \mu \mathrm{m})$ & 5.6 & 42.2 & 38.8 \\
\hline $\mathrm{BHA}+\mathrm{Fe}_{3} \mathrm{O}_{4}$ chem. method & 7.5 & 49.2 & 34.4 \\
\hline $\mathrm{BHA}+\mathrm{Fe}_{3} \mathrm{O}_{4}$ ph.-mech. method & 6.3 & 42.8 & 41.1 \\
\hline
\end{tabular}

thermolysis in the nitrogen medium at $500^{\circ} \mathrm{C}$ for $2 \mathrm{~h}$ showed the absence of any toxic chemicals: the level of iron compounds showed minor changes (Fig. 1). A further study was conducted taking into account the same uniform color of pressed samples and corresponding powders as well as a stable level of iron compounds.

The physical characteristics of the compact materials shown in Table 2 .

Adsorption activity of BHA without ferromagnetic additives was $155 \mathrm{mg} / \mathrm{g}$. In the case of iron-containing sample, obtained by physico-mechanical method, this value is $300 \mathrm{mg} / \mathrm{g}$, while for the material obtained by chemical method - $175 \mathrm{mg} / \mathrm{g}$.

However, by examining the dried compact samples (after complete drying at $25^{\circ} \mathrm{C}$ ), it was found that the pure BHA adsorbed about 5 wt. \% of the drug, while the material obtained by adding the BHA in the process of deposition of iron oxalate 10 wt. \%, the material obtained through precipitation of iron oxalate on the surface of BHA microgranules - about 6 wt. \% .

Comparing the data of the studies of the solution and dried samples it can be argued that the best adsorption properties were in the material obtained by chemical method, because of since the indirect adsorption activity to ceftriaxon it can hold a greater amount of the drug. The pure unalloyed BHA and the material obtained by physicomechanical method can contain a nearly equal number of antibiotic - 5-6\%, while having radically different values of adsorption activity. The reason for such a fact may be partly different specific surface of the starting material, which affects on the structure and value of open/closed porosity.
To understanding the reasons of such experimental data, microphotos of the alloyed samples were studied before and after interaction with the antibiotic solution.

The main part of surface area of the sample, obtained by physico-mechanical method before the experiment (Fig. 2.1, 3.1) held an extensive network of pores smaller than $400 \mathrm{~nm}$ and a small number of larger one $\sim 700-900 \mathrm{~nm}$ localized in some areas of $70-300 \mu \mathrm{m}^{2}$. It is possibly caused by the pressing technological features. There are also grain agglomerates with size of $0.2-0.4 \mu \mathrm{m}$ and small amount of larger than 0.6-0.8 $\mu \mathrm{m}$ located mainly around places with the large pores.

Then after the experiment (Fig. 2.2, 3.2) the antibiotic partial penetration in the sample in the field of localization larger pores $(600-700 \mathrm{~nm})$ and around them the relatively large agglomerates grain size of 0.7-1.5 $\mu \mathrm{m}$ were observed. The rest of the surface with the network of smaller pores was covered by ceftriaxon, reducing the pores size $(<100 \mathrm{~nm})$ and the size of the surrounding agglomerates $(<0.5 \mu \mathrm{m})$.

The microstructure of the material obtained by chemical method, compared with the previous sample has a non-uniform surface that preferably has an extensive network of pores with the size of 450-600 nm. At the same time it is notable many places clusters $\left(<4 \mu \mathrm{m}^{2}\right)$ of smaller pore size less than $300 \mathrm{~nm}$ as well as few surface defects with diameter of $1.8-3.0 \mu \mathrm{m}$ with pores in the size of the order of $300-400 \mathrm{~nm}$ caused by technological features of pressing. Similar to the samples obtained by the physicomechanical method, the above material is 

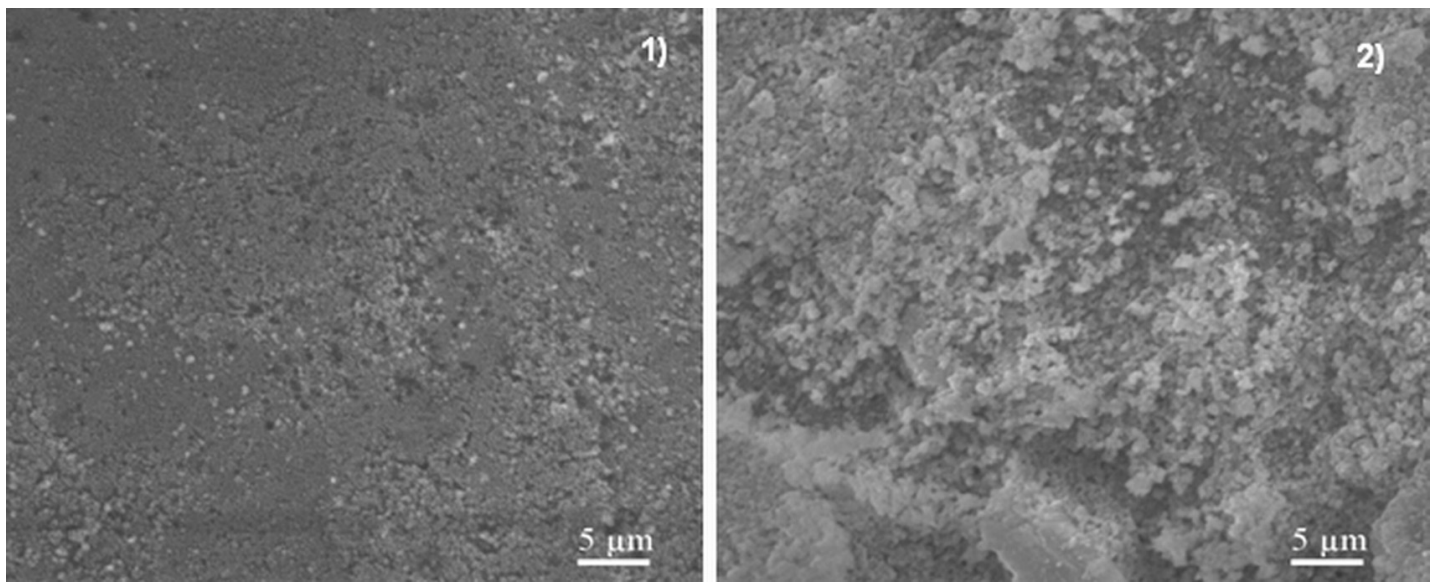

Fig. 2. Microstructure of sample obtained by physico-mechanical method, before (1) and after (2) adsorption of ceftriaxon; $\times 2000$.
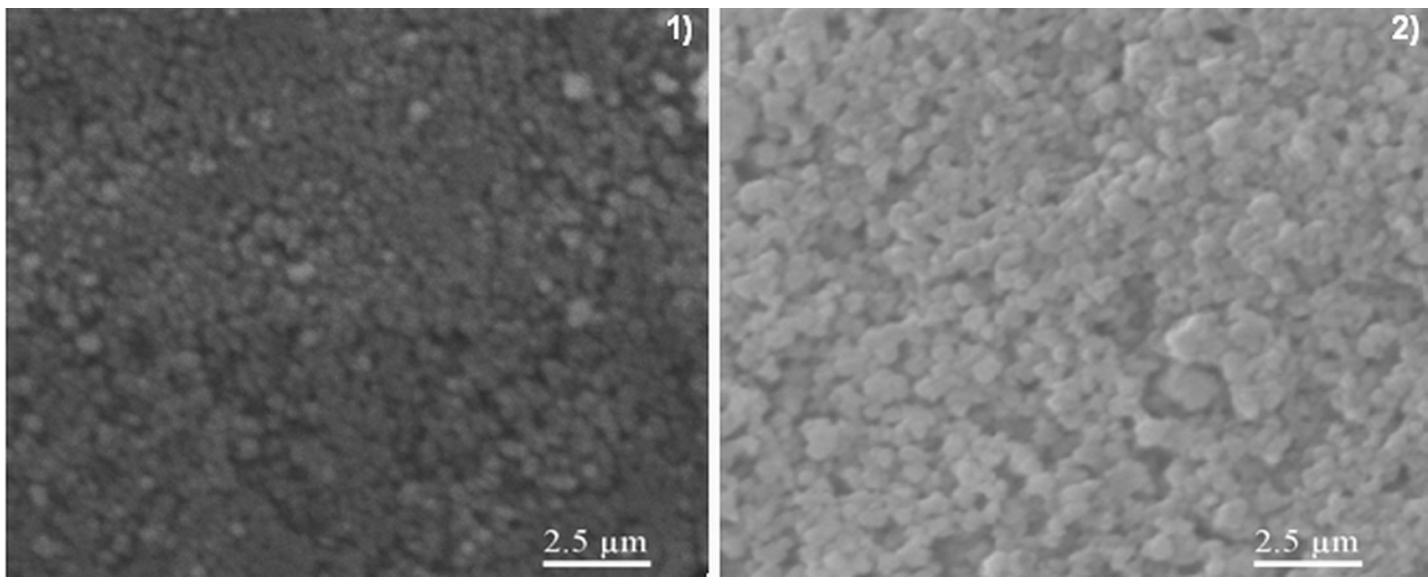

Fig. 3. Microstructure of sample obtained by physico-mechanical method, before (1) and after (2) adsorption of ceftriaxon; $\times 6000$.

also has the agglomerate grain with size near $0.3-0.4 \mu \mathrm{m}$ and separate agglomerates larger than $0.7-0.9 \mu \mathrm{m}$, localized mainly around surface defects (Fig. 4.1, 5.1).

After ceftriaxon adsorption (Fig. 4.2, 5.2) the most of the surface pores represent the pores less than $300 \mathrm{~nm}$ with single randomly located pores larger ( 500-600 $\mathrm{nm}$ ) and surface defects. There are notable also a few localizations of grains agglomerates of $0.5-0.8 \mu \mathrm{m}$ in diameter and the numerous specific surface areas, grain sizes of which are difficult to determine. This may indicate that the drug only in small amount penetrates into the sample (it is possible in the defects areas), thus smoothing their edges and consequently reducing the size. The main amount of the adsorbed antibiotic is based on the sample surface, so it becomes more homogeneous microstructure (mainly through consolidation of small grains).

These differences in the adsorption processes can be explained through the differ- ences between the specific surface areas of the starting powder materials and, consequently, the ratio of the total and open porosity after pressing (Table 2 ).

\section{Conclusion}

As a result of the studing the compact samples of pure biogenic hydroxyapatite and BHA alloyed by ferromagnetic additives using two methods of physicochemical mixing, it was established their complex microstructure. This microstructure depends significantly on the technological characteristics of chosen method for doping the initial biomaterial as well as the ratio closed and open porosity after compression. Analysis of the results and physical parameters of the initial materials indicates probably small tortuosity of capillary-porous structure formed sorption layer on the samples obtained through deposition of previously prepared iron oxalate on the surfaces of BHA microgranules. For almost all open po- 

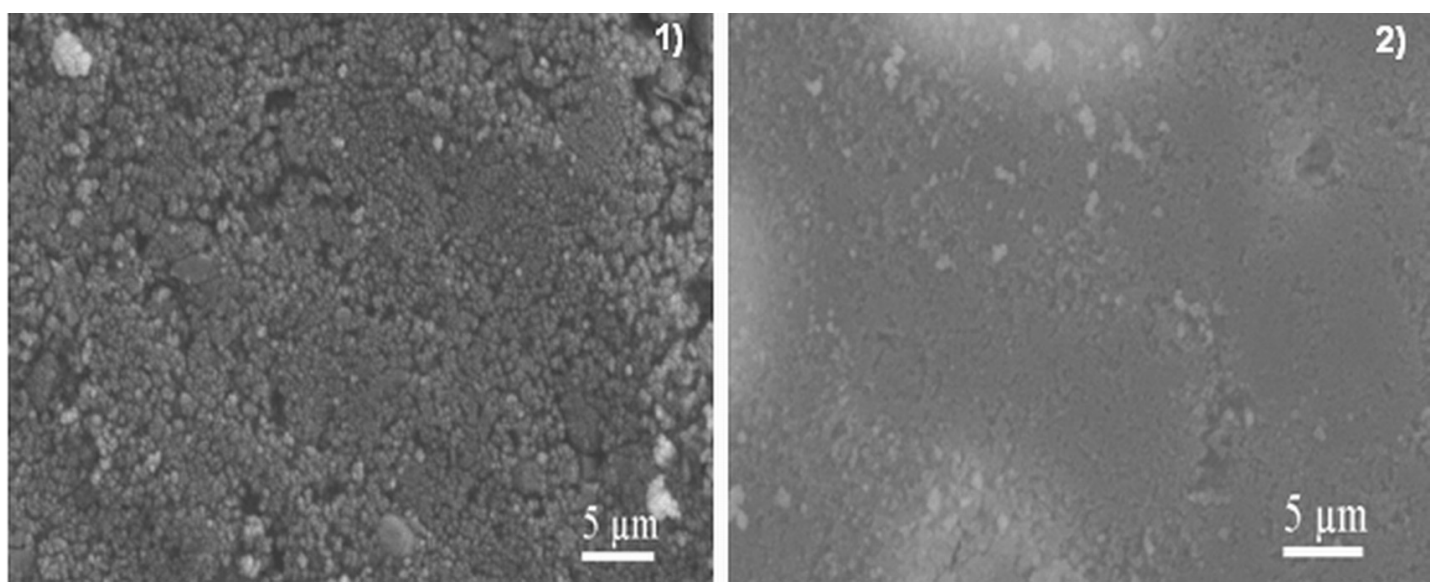

Fig. 4. Microstructure of sample obtained by chemical method, before (1) and after (2) adsorption of ceftriaxon; $\times 2000$.
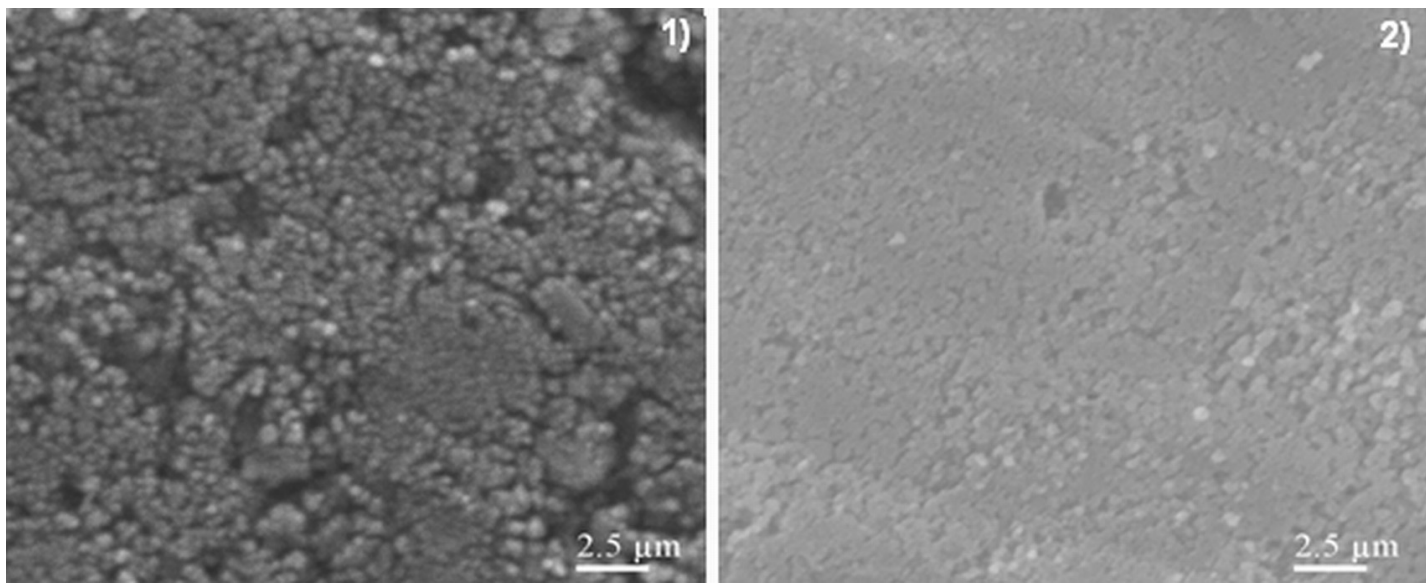

Fig. 5. Microstructure of sample obtained by chemical method, before (1) and after (2) adsorption of ceftriaxon; $\times 4000$.

rosity (41.1\% at $42.8 \%$ of the total), adsorption activity of $300 \mathrm{mg} / \mathrm{g}$ and microstructure characteristic mainly for the drug penetration into the sample, dried residue shows the presence of only 6 wt. \% of the antibiotic. The situation is similar with a the sample of pure BHA, which even with mediate adsorption activity of $155 \mathrm{mg} / \mathrm{g}$ and more open porosity (38.8\% to $42.2 \%$ of the total) could resist only about 5 wt. \% of the starting amount of ceftriaxon. Thus, even penetrating into the material, the active substance is not fixed in it after removal of the solution. The material obtained by chemical method having a much lower adsorption activity of $175 \mathrm{mg} / \mathrm{g}$, but due to the antibiotic penetration into the compact sample and covering its surface is able to hold a nearly twice bigger mass of ceftriaxon (10 wt. \%). This can be explained based on the microstructure of the sample before and after adsorption, showing only a slight penetration of the antibiotic into pressed material that, due to the lower open porosity $(34.4 \%$ over $49.2 \%$ of the total) and, possibly, greater tortuosity of the capillary-porous structure lingers inside.

\section{References}

1. I.Rajzer, E.Menaszek, R.Kwiatkowski et al., J.Mater. Sci:Mater. Med., 25, 1239 (2014).

2. J.Michel, M.Penna, J.Kochen et al., Stem Cells Int., (2015), DOI: 10.1155/305217.

3. V.Campana, G.Milano, E.Pagano et al., $J$. Mater.Sci:Mater.Med., 25, 2445 (2014).

4. S.M.Barinov, V.S.Komlev, Nauka v Rossii, 1, 27 (2005).

5. N.A.Korzh, L.A.Kladchenko, S.V.Malyshkina, Ortopediya, Travmatologia i Protezirovanie, 4, 5 (2008).

6. V.I.Putliaev, Sorosovkii Obrazovatel'niy Zhurnal, 1, 45 (2004).

7. L.Ryden, O.Omar, A.Johansson et al., $J$. Mater. Sci:Mater.Med., 28, 9 (2017).

8. V.A.Dubok, V.V.Protsenko, A.V.Shynkaryk et al., Ortopediya, Travmatologia $i$ Protezirovanie, 3, 91 (2008). 
9. S.A.Filatov, H.S.Kuchinskiy, D.M.Lale et al., in: Int. Sci. Conf. NANSYS-2012, Kyiv, Ukraine (2012).

10. Q.Li, G.Zhou, T.Wang et al., J.Nanomater., (2015), DOI: $10.1155 / 835604$.

11. N.V.Boshitskaya, Powder Metallurgy, 11/12, 3 (2010).

12. S.V.Gorobets, O.Yu.Gorobets, Functional Materials, 19, 18 (2012).

13. P.P.Gorbyk, V.F.Chekhun, Functional Materials, 19, 145 (2012).

14. A.Akbarzadeh, M.Samiei, S.Davaran, Nanoscale Res. Let., 7, 144 (2012).

15. A.V.Razumovskiy, Ratsionalnaya Antibiotikoprofilaktika v Travmatologii i Ortopedii, Moscow (2009) [in Russian].

16. N.V.Ul'yanchich, E.A.Ivaschenko, I.V.Uvarova et al., Ukr. Morph.Al'manah, 8, 44 (2010).

17. O.A.Ivaschenko, Nanostrukturnoe Materialovedenie, 2, 58 (2012).

18. Ya-J.Guo, T.Long, W.Chen et al., Mater. Science and Engineering $C, 33,3583$ (2013).

19. D.Loca, M.Sokolova, J.Locs et al., Mater. Scie. Eng. C, 49, 106 (2015).
20. V.I.Cherniy, A.N.Kolesnikov, I.V.Kuznetsova et al., Novosti Mediciny i Farmatsii, 343, 1 (2010).

21. A.K.Rushai, V.T.Shevchenko, V.H.Pernakova et al., Travma, 2, 1 (2010).

22. V.T.Shevchenko, V.H.Pernakova, E.N.Poddubnaya, Travma, 3, 1 (2010).

23. E.M.Khodosh, Novosti Mediciny i Farmatsii Antimikrobnaya i Protivovirusnaya Terapiya, 310, 1 (2010).

24. UA Patent 61938 (2003).

25. UA Patent 26584 (1999).

26. O.M.Otychenko, T.E.Babutina, O.R.Parkhomey et al., Chem. Phys. Technol. Surf., 1, 10 (2017).

27. V.V.Panichkina, I.V.Uvarova, Methods for Controlling the Dispersion and the Specific Surface Area of Metallic Powders, Naukova Dumka, Kyiv (1973) [in Russian].

28. O.A.Tyazhelov, N.O.Ashukina, H.V.Ivanov et al., Ortopediya, Travmatologia $i$ Protezirovanie, 4, 47 (2006).

29. N.V.Kerymkulova, I.Yu.Torshin, O.A.Gromova et al., Reproductivnaya Endokrinologiya, 4, 101 (2013). 